\title{
Performative Didactics in a Technological Environment
}

\author{
Nadia Carlomagno ${ }^{\mathrm{a}}$, Francesco Maria Cordella ${ }^{\mathrm{b}}, \mathrm{V}$ aleria Minghellic ${ }^{\mathrm{c}}$, \\ Pier Cesare Rivoltella ${ }^{\mathrm{d}}{ }^{[1]}$ \\ ${ }^{a}$ University of Suor Orsola Benincasa, Naples, Italy,nadia.carlomagno@docenti.unisob.na.it, \\ http://orcid.org/0000-0001-8840-1113 \\ ${ }^{b}$ Catholic University of Sacred Heart, Milan, Italy, francescomaria.cordella@unicatt.it \\ ${ }^{c}$ University of Study of Salerno, Naples,vminghelli@ unisa.it, http://orcid.org/0000-0001-7271-5222 \\ ${ }^{d}$ Catholic University of Sacred Heart, Milan, Italy, piercesare.rivoltella@ unicatt.it, http://orcid.org/0000- \\ 0002-8802-0107
}

\begin{abstract}
The didactic-performative experience at a distance, centred on the body in action of the training laboratories activated at the University of Study Cattolica del Sacro Cuore of Milan and the University of Study Suor Orsola Benincasa of Naples, encouraged, through the exercise of 'simplex property' of the separation of functions , the crossing of borders of 'presenceldistance', using Didactics at Distance (DAD) as an opportunity to search in everyone the potential patrimony of the action, able to go beyond the classical meanings of interaction, relationship, experience, emotion, through an effort of imagination and simulation, which even interaction with the machine can stimulate.

The research work recalls the ambivalence and the plurality of interpretative keys of the teaching experience and includes its analogies with the performing arts.

Starting from the 'stage presence', as a scenic 'bios' and source of energy, a third energetic space has been investigated, which can amplify the relational dimension. A space which the biologist Sheldrake defines as 'morphogenetic field' is the one in which it is possible, through the activation of an empathic climate, to make all the processes of emotional sharing, expressive rediscovery and acquisition of awareness sprout, making the experience of DAD a formative and transformative one.
\end{abstract}

Keywords: Performative Didactics at Distance; Extended Mind; Interaction; Presence; Mixed Methods

'Suit the action to the word, the word to the action, with this special observance that you o'erstep not the modesty of nature'.

(Hamlet: Act III, scene II)

\section{Introduction. Overcoming presence and distance paradigms: possible scenarios}

In the current pandemic scenario, in the wake of a didactic and pedagogical tradition that considers teaching as a science of design (Laurillard, 2014), the role of technologies evolves further, confirming the importance of the close

\footnotetext{
${ }^{1}$ Nadia Carlomagno is the main researcher of the project; she designed the project and wrote the sections 'Introduction. Overcoming presence and distance paradigms: possible scenarios', 'Theoretical framework', 'Research design and methodology', 'Research questions', 'Student sample' and 'The performative body'. Francesco Maria Cordella took part in the project and assisted the author in drafting the section 'The working group and the ritual'. Valeria Minghelli elaborated the research data and drafted the sections 'Instruments and procedures', 'Data analysis: quantitative data' and 'Qualitative data'. Pier Cesare Rivoltella is the scientific coordinator of the project; he wrote the section 'Discussion and conclusions: future perspectives'.
} 
relationship between teaching action, regulation and design in a situated form, opening a reflection on training models based on the Virtual Learning Environments. Particularly, pedagogical reflection on interaction mediated by technologies has developed into a space of comparison on the meanings of presence and distance, in a dialectic of antagonism which has led the didactic experience, in the definition of spaces and distances, to a linear model, without considering the possibility of designing methods able to solve the complexity of educational interaction at a distance, through pluralistic and holistic approaches, based on the connection of episodes of situated learning (Rivoltella, 2013) in flexible networks.

These two categories, those of presence and distance, are defined in relation to the use of the body in its perceptive difference, in relation to the limits of a sophisticated and deceptive organisation of knowledge, made up of senses that integrate and give that totality that is different from the sum of the details, a form of perception that combines through sound and vision.

Actually, if we consider the body in action, teaching and learning in the presence of other bodies and objects and in a shared space that animates the formative experience, supporting the 'nature' of human action, the presence experience is proposed as the only natural form of experimenting in the educational field. If, otherwise, we consider all the possible modes of action in the educational field that support the body 'as the main device through which, by carrying out experiences, we develop learning and produce knowledge' (Rivoltella, 2012, p. 109), the body appears capable of evolving with the physical and virtual environment in an enactive logic (Rossi, 2011) and in an intersubjective time and space (Gallese, 2007). Therefore, a presence that is no longer only physical, but that finds its space in other forms of interaction, including digital ones, preferring a laboratory teaching centred on the body in situation (Rivoltella, 2017) is the focus of this explorative research.

From this point of view, the Didactic Laboratory at Distance (DLaD), centred on the body in action, carried out in the training workshops activated at the Catholic University del Sacro Cuore of Milan and the University of Studies Suor Orsola Benincasa of Naples, between March and June 2020, at the first lockdown, is not tested as an immaterial form of perception, nor as an exercise of the rational in the context of training, but as a predisposition of a system of relationship, that, in a condition of physical distance, has been called to explore certain ways of research on the interactive and communicative potential of the body, at a distance, through the use of education and communication technologies (Laurillard, 2014), supporting in this sense the idea that 'technology is a network of relationships [...]', which mediates between humans and nature and as it extends, it develops and produces new relationships between people, between things and between people and things' (Simondon, 2001; Gallese, 2020).

In the light of the reflections that emerged, in fact, in the teaching-performative experience at a distance, the exercise of the function separation and rapidity properties has been tested, along with the evergreen principles of deviation (Berthoz, 2011) and créatrice inhibition (Berthoz, 2020), masterfully described by neurophysiologist Alain Berthoz.

Every possible communicative and perceptive modality capable of elaborating a surplus of signification (Varela, 1999), however, applied in the didactic field, has been investigated, translating the interaction between biological and cognitive properties (Frauenfelder, 2001) into action, developing and enhancing creativity 'that is expressed in the endless search for solutions to solve the problems that daily life poses'. Through 'creativity, that is, the ability to imagine and formulate hypotheses, the human species has been able to achieve those prodigious technologies that have allowed to amplify its biopsychological potential and build that multiplicity of symbolic systems ranging from sciences to the arts' (Pinto Minerva, 2011, p. 49).

\section{Theoretical framework}

In the current scenarios of educational research, the training process has taken on the characteristics of an interdisciplinary, dynamic, integrated, complex and systemic approach, generated by non-linear survey needs (Sibilio, 2014) that 'postulate a holistic and protean vision and a complex and biopsychosocial perspective of corporeity' (Carlomagno, 2014, p. 186). So, conceptual knowledge is mapped into our sensorimotor system that 'characterizes the semantic content of concepts in accordance with the way we work in the world with our body' (Gallese \& Lakoff, 2005). In this perspective, teaching can take explicit and implicit forms of dynamic representations to support a view of knowledge as an active process, rooted in the body and biological structure of the individual (Maturana \& Varela, 1980) through the subjective experience of reality. In this perspective, the body becomes the premise of interaction with the environment (Frauenfelder, 2001), repositioning the relationship as the foundation of the teaching experience in analogy with the artistic experience, confirming '[...] a change of perspective that takes into account the different levels by which my consciousness is indistinguishably linked to that of others and to the phenomenal world in an empathetic "coacervo"” (Varela, trad. it, 2006, p. 79).

In such a vision, the structural coupling teacher-learner and similarly director-actor and actor-spectator (Maturana \& Varela, 1980; Rossi, 2011) is possible only if the meetings are considered from the perspective of the 
system itself: 'knowledge is neither outside us [...] nor only within us [...]; it is in the emergency space where acquaintance and known meet and co-influence' (Proulx \& Simmet, 2013), highlighting an expanded space of action of the body: 'The body interacts its environment in a straightforward way. These interactions are of the nature macrophysical encounters - sensory transduction, mechanical performance, and so on - nothing surprising about them' (Varela, 1999, p. 56).

The body in action is, therefore, generative of an unexplored perceptive space, which in the DLaD also can act and encourage conceptualisation, intervening in the recursive process (Rossi, 2011) intrapersonal and express explicitly in the artistic experience acting the contents apparently present only in the artist's mind (Gallese \& Morelli, 2011, p. 2). The dimensions of the reified relation in the mirror circuit (Gallese et al., 1996; Rizzolatti et al., 1996) allow us to corroborate, therefore, the correspondence among perception, intention and motor simulation. In this reading key, the artistic experience, and its modalities, operated in the didactic field, realise imitative and mimetic functions placed at the base of the mental tuning, connoting the body as a mediator of the interpersonal dimension (Gallese \& Morelli, 2011, p. 2).

Corroborating the idea that teaching is theatre and theatre is teaching (Rivoltella \& Rossi, 2017), the thesis is reinforced that the theatrical (Fischer-Lichte, 2014) and the didactic events, both based on incarnate action, can and should share certain fundamental elements, first of all, to possess and pursue one's own performative nature (Rivoltella, 2017), that is, the didactic action that is constituted in fieri, hic et nunc, and that makes use of a daily replicability (think of the theatrical replicas), 'which is not equivalence but a constant remodeling, as it happens in the theater, with a flexible, creative mode, susceptible to variations, permeable to a series of elements that concur chaotically' and that allows 'to interpret in the body and through the body a variety of forms that are translated into the richness of its meanings' (Carlomagno, 2020, p. 351). In fact, teaching, as happens for the theatre, not only makes use of the syntactic level of communication, oriented to 'pass' a concept, a message, an action, an emotion, through the use of the voice, the body and the gesture, but also makes use of a communication that, moving on the semantic level, points in laboratory teaching to understanding the sense, sometimes even implicit (Perla, 2010) and then to effective communication, based on the pragmatic level (Morris, 1938) of communication.

We support in this sense, the pre-expressive level '[...] a pragmatic category, a practice that during the process aims to develop and organize the actor's scenic "bios" and to bring out new relationships and unexpected possibilities of meanings' (Barba, 1993, p. 163), thus producing transformative effects on the actor-learner.

\section{Research design and methodology}

The research was designed supporting the paradigms of design-based research (DBR) by Anne Brown (Rivoltella \& Rossi, 2019) and analysing quantitative data in the first instance; in the second phase, metacognitive reflections, currently under consideration, will be analysed according to the integrated design (Greene \& Caracelli, 1997) in a holistic (Forbes, 2003) and transformative (Mertens, 2007) perspective.

\subsection{Research questions}

In structuring the design of the exploratory study, two different research questions have been investigated:

- to understand whether, even at a distance, it is possible to strengthen the conscious, competent and responsible bodily action of the teacher by planning and implementing a teaching that recognises the performative role of the body as a tool of relationships and cognition and

- to outline the elements and structures of a new model of teaching, implemented by the awareness emerged from the DLaD, by the knowledge and exercise of the properties and principles of simplexity proposed by Alain Berthoz in his theory on simplexity, through dialogue between the body and technologies.

\subsection{Student sample}

A sample of 1069 students surveyed (M 21, F 1141, NS 7) corresponds to all students involved in the different training courses that have declined the methodology described in the DLaD, set on the same methodological and scientific framework, the choice is determined by the possibility to administer the questionnaire to all students, allowing to reach a large number of people. Specifically, these are courses such as 'Laboratory of didactic dramaturgy' of the degree course in Sciences of Primary Education of UniCatt of Milan; Master in 'Theatre, pedagogy and didactics, technical methods and practices of the performing arts' of UNISOB of Naples; 'Laboratory of Didactics Area of body- 
movement' of the degree course in Sciences of the Primary Formation and 'Playing you learn, creative techniques for the animation and the theatrical communication' and 'Design and evaluation of educational interventions in early childhood' of the degree course in Education Sciences of the UNISOB.

\section{Implementation of the didactic device for the constitution of the classroom setting of DLaD}

\subsection{The working group and the ritual}

The remodelling of the training course began by redefining a new concept of space to be assimilated to the DLaD in order to create a classroom setting suitable for the new condition of social distance.

Endorsing the idea that space is not itself a form, but that it produces forms in structuring interaction relationships (Simmel, 1998), a third-energy space has been explored (Potter \& McDougall, 2017), activating the interaction between the participants in the same unity of dialogue (Varela, 1999), in which everyone could perceive themselves present in the here and now, a place where information could be mirrored, and emotional states resounded without fear of external or aesthetic judgements.

In DLaD, where class groups are formed by up to 50 students, the classroom laboratory setting uses, as happens in the experiences in the presence, the rule of the suspension of judgement (Rogers, 2013) and is realised activating a suggestive stimulation of the imagination (Vygotskij, 1972) that allows the whole group to tune and align, according to a teacher-learner, director-actor coevolution. In an integrative key, some artistic experiences, transformed by the educational laboratory into a digital environment, imply that the teacher-director guides the individual and the group through training (Carlomagno, 2020), that is, paths of bodily exploration based on breathing and tending to expand the plane of consciousness, generating a new dimension where one has the perception of being connected, in an expanded space, which works to overcome the physical distance.

'The actor's work in fact, as well as the teacher's work, is primarily a work on himself, involving him as an integral human being: body, mind and soul, external and internal, expressiveness and emotions that using theatrical techniques, matured through training, transforms the techniques of acting' (Carlomagno, 2020, p. 356) in 'ways to a discipline of the self, to obtain an expansion of perception and perhaps of consciousness' (Taviani, 1997, p. 145).

This activation is a necessary condition for generating the morphogenetic field (Sheldrake, 2009) based on an open and dilated body (Barba \& Savarese, 2011, p. 33) to perception, in which the virtual classroom is circumscribed, capable of translating into a 'metaphysical classroom', a different physical space, symbolic and representative of perception and action. With the setting structured, the teacher's task is to share with the participants the tools for understanding the new relational process through the procedure of 'ritual' (Turner, 1993), which determines the community dimension of the classroom triggering, thus, the process of transformation. 'Rites are collective memories inscribed in actions [...] they help people to face the difficulties of moments of transition, the ambiguity of relationships, hierarchies and desires that complicate, jeopardize or violate the rules of daily life. [...] Ritual and play guide people to a further reality, distinct from ordinary life [...] one in which people can experience other selves than usual ones' (Schechner, 2018, p. 111).

In this view, the rite may take on the connotations of a means that allows participants to extend mutual contact beyond space-time borders, into the Extended Mind, which as a seventh sense (Shaldrake, 2006, p. 22), generates the acquisition of awareness of the presence in the here and now (Carlomagno, 2020), both individually and collectively, keeping the empathic level constantly active.

\section{Iconographic documentation}

In the description of the setting, in the immateriality of distance training, the context has taken on the connotations of the relationship in which the technological interface, which in our case has materialised on the digital platforms Meet and Blackboard, has been established both as a means and as a generating part of the training process. For the laboratory activities, focused on the performative body, students were divided into smaller subgroups consisting of up to five people. In this new spatial dimension, communication has become embodied performative communication, manifesting the peculiarity of each one through free action to activate fantasy and creativity (Guilford, 1950), without constraints and prejudices, thus manifesting one's own higher self (Choa, 2020).

Starting from these presuppositions, the didactic instruments have been addressed to the exercise of the simplexity in the laboratory action, experiencing adaptive functions like separation and rapidity and rules of action like probabilistic anticipation and vicariance (Berthoz, 2011).

In rethinking the laboratories in $\mathrm{DLaD}$ were remodulated everything that would have characterised the performance of the body in teaching in the presence, using the principle of vicariance (Berthoz, 2015) as a device and strategic resource to cope with the new and compensate for what would have been lacking by operating at a distance if the 
organism develops an adaptive behaviour in dealing with complexity. It was essential to design the lessons by applying the property of rapidity, although hetero determined, that crossed with the principle of probabilistic anticipation to face in fast times possible effective innovative scenarios.

The function separation property, whereby 'in every system of living organisms, from molecular to social, there is a separation of specialized functions that cooperate with each other' (Berthoz, 2011), has been declined in the field of communicative expressive functions of teaching communication, separating and regulating the use of the verbal and paraverbal codes, that is, the exercise of using voice of the director-teacher and the actor-learner through the modulation of height, tone, intensity, timbre and voice. The use of the body in expressive actions has foreseen the use of gesture used in diachronic and synchronic forms through the expression and the exploration of abstract and concrete concepts of emotions and narrations of the body (facial-proxemic mimic) in the simulation-interpretation of dramaturgy-storytelling and a lesson. Finally, through the use of graphic and iconic signs (Goodman, 1968), the attention was focused on the photographic and video language that resumed the performative work of the actors. The experience has allowed to review, with a teaching lens, their performance to activate reflection (Schön, 1993) and awareness of the unconscious use of non-verbal communication and gestural mimicry and the importance of it in transmission of the message.

\section{Instruments and procedures}

\subsection{The structure of questionnaires}

In order to verify the results of the work carried out, a self-administered questionnaire was developed through a Google module, which aimed to investigate the perceptions of the experiences of students, declared about laboratory experiences in DLaD. The survey tool was developed following a first experience in DLaD, where feedback was investigated to support the educational relationship and in which metacognitive reflections were being analysed and will be the subject of a subsequent study; it also became necessary to investigate the issue of corporeality in the context of DLaD experiences.

The questionnaire was administered in a pre-test to a sample of students from previous courses, in which the questions were made clear and easily usable. The number of items had also been reduced to avoid redundancy.

The questionnaire had been organised into 11 items, of which three pertained to personal data collection (IT A 1-3: age, gender, degree course attended) and eight items were intended to investigate around the topics simulation, exploration, body-expressive activity, communicative body activity, body and movement, knowledge, communicative potential and non-verbal communication (IT B 1-8) (Table 1).

\begin{tabular}{ll}
\hline Item & \\
\hline B1 & Simulation \\
\hline B2 & Exploration \\
\hline B3 & Body-expressive activity \\
\hline B4 & Communicative body activity \\
\hline B5 & Body and movement \\
\hline B6 & Knowledge \\
\hline B7 & Communicative potential \\
\hline B8 & Non-verbal communication \\
\hline
\end{tabular}

Table 1 Questionnaire structure

Learners were asked to indicate a value in an organised response for multiple indicators (Baldacci \& Frabboni, 2013) on a Likert scale in four values from 0 to 3, where 0 corresponded to 'never', 1 to 'sometimes', 2 to 'often' and 3 to 'always'. Students were informed in advance of the purposes of the research and provided the questionnaire in anonymous form at the end of the lessons, after giving their informed consent, in a specific section of the Google module.

The closed questionnaire was aimed at collecting quantitative data in relation to the first question of research, while qualitative data, which will be analysed in the future by specific analysis software, can contribute to a more complete view by opening up new reflections around the second question of research.

Although the analysis of qualitative data is not the subject of this contribution, the methods collected are defined below in accordance with the research plan which aims to be structured in the future, within the approach of Mixed 
Methods Designs, promoting interdisciplinarity and the integration of quantitative and qualitative methods (Creswell \& Plano Clark, 2018; Giovannini \& Marcuccio, 2012).

\subsection{Qualitative tools}

The qualitative data were derived from metacognition activities structured in the final section of the laboratories where the students had to fill in a metacognitive reflection sheet that was divided into two parts:

- Laboratory activities. In this section, the students had to mark a timeline of the activities with an analytical description of the stages of the process.

- Logbook. Personal reflections on the experience of the laboratory, in which, starting from the activities carried out and the skills acquired, have produced a critical reflection on the possible declination of the languages tested in educational use. Finally, the students answered some open-ended questions investigating the strengths and weaknesses of the DLaD experience.

\section{Data analysis: quantitative data}

The questionnaire (Table 2) aimed to stimulate reflection on the perceptions of the experiences of each learner about the laboratories carried out in distance teaching, in order to investigate the reason of participation of the presence in the distance and the transformative potential of a teaching so conceived and implemented. To reflect on the data that emerged from the survey, we report description of the data in Table 2.

With the first item (IT B1), the students were asked if the laboratory in distance didactics had allowed the simulation. For this, $91.9 \%$ of the sample answered in a positive way. This data was divided between $52.9 \%$ that answered 'always' and 39\% that answered 'often'. It was asked again if the laboratory in distance didactics had allowed the exploration (IT B2). In this case also, the meaningful data of $90.5 \%$ of the total sample had answered in a positive way. To the question whether the laboratory had allowed the exercise of bodily or expressive activities (IT B3), $93.5 \%$ of the total sample answered yes, of which $63.7 \%$ answered 'always' and $29.8 \%$ answered 'often'; $94 \%$ of the total sample declared that the laboratory teaching at a distance has allowed the exercise of communicative body activities (IT B4). To the question asking them to declare if the laboratory had allowed to recognize in every knowledge a bond with the body and with the movement (IT B5), 61.2\% answered 'always' and 31.9\% answered 'often' in $93.1 \%$ of the total sample.

A total of $94.6 \%$ of the students stated that the laboratory allowed to discover a new way of learning knowledge of various types (IT B6); it was still asked if it was possible to explore their own communicative potential (IT B7), for which $37.6 \%$ answered 'often' and 54.6\% answered 'always', confirming again a positive answer for a total of $92.2 \%$. Finally, a total of $89.1 \%$ of the sample reported that the laboratory allowed to explore a mode of learning without the use of the word (IT B8).

The data collected would seem to support, as a whole, the possible digital declination of the educational laboratory in its $\mathrm{DLaD}$ form and its educational effectiveness in the perception of participants, confirming a widespread perception, by actors, of the expressive possibilities of the body in DLaD and the awareness, deriving from the formative experience, to possess and to be able to refine one's ability to perform one's own body, in experiencing contents, texts or other objects of knowledge, in a logic of interaction and exchange.

\section{Qualitative data}

The qualitative investigation, which relates the personal repercussions with the definition of the timeline, described in the final stage, gives useful information on the discussion of the second question of the research. The metacognitive tool provided further information about the relapses that the students have identified as the strength of this experience, confirming the acquisition of a greater awareness of the potential of one's own body and the potential of its languages, of non-verbal communication. These qualities are often underestimated within the educational and training courses.

The results of the qualitative survey are still under analysis and interpretation due to the size of the sample. Conceptual macro-categories are being identified, within which the explored categories are included, using tools that will allow a rigorous and accurate analysis of the data. Herewith, some reflections refer to only some macro-categories: body awareness, body communication, listening and relationship skills. Awareness of the hermeneutic power of qualitative data follows some students' reflections in the above categories, which, among others, encourage everybody to further conduct quality investigation to support quantitative data.

F. M. of laboratory group n.10 declares: 'I have learned to sharpen my awareness about the body. I have learned to listen to it and I will do it more often, and I hope that this new consciousness will lead me to pay more attention to the 
unconscious communication of the body'. Instead, V. N. of group 6 claims, 'I learned that you can't not communicate. Verbal and body language are closely connected in that the one conditions the meaning of the other determining the effectiveness of the message and, therefore, of the didactic action. I will pay attention to the body of my future students'. This last reflection returns the sense of the open response, placed at a metacognitive level, stimulated by perceptions lived in the first person. The body-centred laboratory experience (S. D. P., group 9) 'has allowed a realisation of her communicative ability and of her being protagonist, even unconscious, in every situation. After all, also in didactic, as August Boal (2011) says, theatre is this: the art of seeing ourselves, the art of seeing ourselves'.

Through the application of the device, starting from the paradigm of the extended mind, we have pursued the potential of implementing the evocative power of experiences, narratives and suggestions. In this perspective, the metaphor of the virtual has been extremely fitting to provide the image of social reticular hypertextual connections that, even in the absence of bodies, have had the opportunity to exist and multiply

Table 2 Frequency distribution table

\begin{tabular}{|c|c|c|c|c|}
\hline Item & Questions & $\begin{array}{l}\text { 4-point Likert } \\
\text { scale }\end{array}$ & Frequency & $\begin{array}{l}\text { Percentage } \\
\%\end{array}$ \\
\hline \multirow[t]{5}{*}{ B1 } & \multirow[t]{5}{*}{ The laboratory in DAD (Didactics at Distance) allowed the simulation } & Never & 12 & 1.1 \\
\hline & & Sometimes & 75 & 7 \\
\hline & & Often & 417 & 39 \\
\hline & & Always & 565 & 52.9 \\
\hline & & Total & 1069 & 100 \\
\hline \multirow[t]{5}{*}{ B2 } & \multirow[t]{5}{*}{ The laboratory in DAD (Didactics at Distance) allowed the exploration } & Never & 12 & 1.1 \\
\hline & & Sometimes & 90 & 8.4 \\
\hline & & Often & 439 & 41.1 \\
\hline & & Always & 528 & 49.4 \\
\hline & & Total & 1069 & 100 \\
\hline \multirow[t]{5}{*}{ B3 } & \multirow{5}{*}{$\begin{array}{l}\text { The laboratory in DAD (Didactics at Distance) allowed the exercise of expressive } \\
\text { body activities }\end{array}$} & Never & 7 & 0.7 \\
\hline & & Sometimes & 63 & 5.8 \\
\hline & & Often & 318 & 29.8 \\
\hline & & Always & 680 & 63.7 \\
\hline & & Total & 1068 & 100 \\
\hline \multirow[t]{5}{*}{ B4 } & \multirow{5}{*}{$\begin{array}{l}\text { The laboratory in DAD (Didactics at Distance) has allowed the exercise of } \\
\text { communicative body activities }\end{array}$} & Never & 5 & 0.5 \\
\hline & & Sometimes & 58 & 5.5 \\
\hline & & Often & 349 & 32.9 \\
\hline & & Always & 648 & 61.1 \\
\hline & & Total & 1060 & 100 \\
\hline \multirow[t]{5}{*}{ B5 } & \multirow{5}{*}{$\begin{array}{l}\text { The laboratory in DAD (Didactics at Distance) has allowed to recognize in every } \\
\text { knowledge a link with the body and movement }\end{array}$} & Never & 5 & 0.5 \\
\hline & & Sometimes & 69 & 6.4 \\
\hline & & Often & 341 & 31.9 \\
\hline & & Always & 654 & 61.2 \\
\hline & & Total & 1069 & 100 \\
\hline \multirow[t]{5}{*}{ B6 } & \multirow{5}{*}{$\begin{array}{l}\text { The laboratory in DAD (Didactics at Distance) has allowed to discover a new way } \\
\text { of learning knowledge of various types }\end{array}$} & Never & 6 & 0.6 \\
\hline & & Sometimes & 51 & 4.8 \\
\hline & & Often & 387 & 36.2 \\
\hline & & Always & 624 & 58.4 \\
\hline & & Total & 1068 & 100 \\
\hline \multirow[t]{5}{*}{ B7 } & \multirow{5}{*}{$\begin{array}{l}\text { The laboratory in DAD (Didactics at Distance) has allowed to explore its } \\
\text { communicative potential }\end{array}$} & Never & 8 & 0.7 \\
\hline & & Sometimes & 75 & 7 \\
\hline & & Often & 402 & 37.7 \\
\hline & & Always & 584 & 54.6 \\
\hline & & Total & 1069 & 100 \\
\hline \multirow[t]{5}{*}{ B8 } & \multirow{5}{*}{$\begin{array}{l}\text { The workshop in DAD (Distance Teaching) allowed to explore a mode of learning } \\
\text { without the use of words }\end{array}$} & Never & 27 & 2.5 \\
\hline & & Sometimes & 90 & 8.4 \\
\hline & & Often & 406 & 38 \\
\hline & & Always & 546 & 51.1 \\
\hline & & Total & 1069 & 100 \\
\hline
\end{tabular}




\section{Discussion and conclusions: future perspectives}

In the light of the experience gained and reflected in the qualitative and quantitative surveys, it is possible to confirm that the didactic laboratory, which is the subject of this exploratory study, has made it possible to answer the first research question that the model tested and the results of quantitative and qualitative instruments of investigation have helped to promote a perception of distance as an experience of the interaction possible, also for experiences characterised by a physical and spatial identity of presence, like those which are expressive, relational and interpretative that characterise the performing arts.

The design of the activities carried out confirmed the holistic perspective in the relationship between technology and education (Rivoltella \& Rossi, 2019). The exploration of possible interactions body-man-machine (Rivoltella \& Rossi, 2019) defining micro-elements design that allowed to define an innovative model in the use of the body and space. 'Technology as a catalyst is effective only when used to enable learning with richer content, more powerful pedagogy, more valid assessments, and links between in-and out-of-classroom learning' (Dede, 2014). In this reading, the body and the machine have marked a mode of interaction indispensable to face the challenges of educational complexity (Rivoltella \& Rossi, 2019). In conclusion, in promoting dialogue between the performing arts and educational research, the declination of the principles of simplexity has allowed establishment of an original experience, reworked in the $\mathrm{DLaD}$, without renouncing to the perceptive immersivity, to the empathic relationship and to the contagion proper to the acting action.

The work, in the opinion of about 1000 students interviewed, offered us a new space of presence still little explored by theatrical training, or technological mediation, in which to exercise vicariance, the deviation from the linearity between the action of the teacher and the action of the learner, the separation and the circumscribed use some modalities of the action in order to realise the same communicative function. This extraordinary opportunity for experimentation has opened and partly answered the second question, giving rise to the need for a new interactive model mediated by the use of the digital interface and structured on the new vision of the presence as circulating energy among all the actors of the formative process that generates a transforming force and, in this sense, vital form, supporting the 'radical concept of presence' (Fischer-Lichte, 2014, p. 175).

In retracing backwards the design elements, the tools of simplexity and the strategies implemented in the emergency distance, we looked at the paradigms of DBR by Anne Brown, building a research design oriented according to the Mixed Methods (Creswell \& Plano Clark, 2018). In this perspective, the experience has been constituted as a pilot project, already replicated in the laboratories of the first semester of this academic year, with the introduction of corrective elements of implementation, consistent with the principles of Design-Based Implementation Research (DBIR) designed in the light of emerging reflections (Rivoltella \& Rossi, 2019).

In conclusion, recalling Hattie's research work, we can support the hypothesis that 'the impact of technologies on learning depends on the teacher and the strategies she adopts' (Hattie, 2009).

\section{References}

Baldacci, M. \& Frabboni, F. (2013). Manuale di metodologia della ricerca educativa. Milano: Utet.

Barba, E. (1993). La canoa di carta, Trattato di antropologia teatrale. Bologna: Mulino.

Barba, E. \& Savarese, N. (2011). L'arte segreta dell'attore. Dizionario di antropologia teatrale. Bari: Edizioni di Pagina.

Berthoz, A. (2011). La semplessità. Torino: Codice.

Berthoz, A. (2015). La vicarianza. Il nostro cervello creatore di mondi. Torino: Codice Edizioni.

Berthoz, A. (2020). L'inhibition créatrice. Parigi: Jacob.

Boal, A. (2011). Il teatro degli oppressi. Teoria e tecnica del teatro. Molfetta: La Meridiana.

Carlomagno, N. (2014). La dimensione assiologica: scopi. Autonomia responsabile e benessere nel curriculo dell'Educazione Motoria. In Lipoma, M. (a cura di). Educazione motoria. Lecce: PensaMultimedia.

Carlomagno, N. (2020). Le potenzialità didattiche delle arti sceniche. Education Sciences \& Society. 1. ISSN 20389442, ISSNe 2284-015X. Doi: 10.3280/ess1-2020oa9941.

Choa, K. S. (2020). Raggiungere l'unione con l'anima superiore. Meditazione per la realizzazione dell'anima. Roma: Edizioni mediterranee.

Creswell, J. \& Plano Clark, V. (2018). Designing and Conducting Mixed Methods Research, Thousand Oaks: Sage.

Dede, C. (2014). The role of digital technologies in deeper learning. Students at the Center: Deeper Learning Research Series. Jobs for the future. Harvard University. December.

Fischer-Lichte, E. (2014). Estetica del performativo. Una teoria del teatro e dell'arte. Roma: Carocci Editore. 
Forbes, S. (2003). Holistic Education: An Analysis of its Ideas and Nature. Brandon, VT: Foundation for Educational Renewal.

Frauenfelder, E. (2001). Pedagogia e biologia. Una possibile «alleanza». Napoli: Liguori.

Gallese, V., Fadiga, L., Fogassi, L. \& Rizzolatti, G. (1996). Action recognition in the premotor cortex. Brain, 119 (Pt 2).

Gallese, V. \& Lakoff, G. (2005). The brain's concepts: The role of the sensory-motor system in conceptual knowledge. Cognitive neuropsychology, 22(3-4), 455-479.

Gallese, V. (2007). Dai neuroni specchio alla consonanza intenzionale. Meccanismi neurofisiologici dell'intersoggettività. Rivista di Psicoanalisi, LIII, 1, 197-208.

Gallese, V. \& Morelli, U., (2011, february). Il teatro come metafora del mondo e il teatro nella mente. Nell'ambito del ciclo di incontri su Il teatro come metafora del mondo. Laboratorio filosofico sulla complessità. Castiglioncello (Pi).

Gallese, V. (2020). Estetica dell'intersoggettività. Sé e relazioni nell'era digitale. Psiche, V. 2, luglio-dicembre ISSN: 1721-0372. DOI: 10.7388-99024, 403-414.

Giovannini, M.L. \& Marcuccio, M. (2012). La valutazione di ricerche pedagogiche con 'metodi misti' da parte dei referee: tra criteri di qualità e aspetti problematici. In AA.VV. Il futuro della ricerca pedagogica e la sua valutazione (pp. 272-287). Roma: Armando.

Goodman, N. (1968). Languages of Art, Indianapolis, Hackett; (tr. it.) I linguaggi dell'arte, Milano, Il Saggiatore, 1976. Greene, J. C. \& Caracelli, V. J. (eds.) (1997). Crafting mixed-method evaluation designs. Advances in mixed-method evaluation: The challenges and benefits of integrating diverse paradigms. New directions for evaluation. $n$. 74, San Francisco, Jossey-Bass, 19-32.

Guilford, JP (1950). Creatività. American Psychologist, 5 (9), 444-454. https://doi.org-10.1037-h0063487.

Hattie, J. (2009). Visible learning: A synthesis of over 800 meta-analyses relating to achievement. London, New York: Routledge.

Laurillard, D. (2014). Insegnamento come scienza della progettazione. Costruire modelli pedagogici per apprendere con le tecnologie. Milano: Franco Angeli.

Maturana, H. R. \& Varela, F. G. (1980). Autopoiesis and Cognition. Dordrecht: Reidel.

Mertens, D. M. (2007). Transformative paradigm: mixed methods and social justice. Journal of mixed methods research, n. 1., 212-225.

Morris, C.W. (1938). Foundations of the theory of signs. In Neurath, O. et al. (eds.). International encyclopedia of unified science, Col. 7, N.2. Chicago. Pp. 77-137.

Perla, L. (2010). Didattica dell'implicito: ciò che l'insegnante non sa. Brescia: La Scuola.

Pinto Minerva, F. (2011). L'età adulta tra permanenza e mutamento. Pedagogia oggi. 1-2-2011. Semestrale Siped. Tecnodid.

Potter, J. \& McDougall, J. (2017). Digital Media, Culture and Education: Theorising Third Space. Springer.

Proulx, J. \& Simmet, E. (2013). Enactivism in mathematics education: moving toward a reconceptualization of learning and knowledge. Education Sciences \& Society, IV, 1. In Rossi, P.G. \& Pezzimenti, L. (2015). Dalla prospettiva di studente a quella di docente. Giornale Italiano della Ricerca Educativa, anno VIII, numero 14, giugno, 341-353.

Rivoltella, P.C. (2012). Neurodidattica. Milano: Raffaello Cortina Editore.

Rivoltella, P.C. (2013). Fare didattica con gli EAS. Episodi di Apprendimento Situato. Brescia: La scuola.

Rivoltella, P.C. (2017). Corpi in situ-azione: presupposti neuroscientifici e drammaturgici per una nuova formazione degli insegnanti. In La professionalità degli insegnanti. La ricerca e le pratiche. (pp. 89-99). Lecce: PensaMultimedia.

Rivoltella, P.C. \& Rossi, P.G. (a cura di) (2017). L'agire didattico. Manuale per l'insegnante. Brescia: La Scuola.

Rivoltella, P.C.\& Rossi, P.G. (2019). Il corpo e la macchina. Tecnologia, cultura, educazione. Brescia: Morcellania.

Rizzolatti, G., Fadiga, L., Gallese, V. \& Fogassi L. (1996). Premotor cortex and the recognition of motor actions. Cognitive Brain Research, 3, 131-141. DOI: 10.1016-0926-6410(95)00038-0.

Rogers, C. (2013). La terapia centrata sul cliente. Firenze: Giunti.

Rossi, P.G. (2011). Didattica enattiva. Complessità, teorie dell'azione, professionalità docente. Milano: Franco Angeli.

Schechner, R. (2018). Introduzione ai performance studies. Imola: Cue Press.

Schön, D.A. (1993). Il professionista riflessivo. Bari: Dedalo.

Sheldrake, R. (2006). La Mente estesa-il senso di sentirsi osservati e altri misteri inspiegati della mente umana. Milano:

Feltrinelli.

Sheldrake, R. (2009). New Science of Life. Third edition. Icon book.

Sibilio, M. (2014). La Didattica Semplessa. Napoli: Liguori Editore.

Simmel, G. (1998). Sociologie. UntersuchungenüberdieFormenderVergesellschaftung. Sociologia. Torino: Edizioni Comunità.

Simondon, G. (2001). L'individuazione psichica e collettiva. Roma: Derive Approdi.

Taviani, F. (1997). Passaggi e sottopassaggi. Esercizi di terminologia. In: De Marinis M., (a cura di). Drammaturgia dell'attore. Porretta Terme. I Quaderni del Battello Ebbro.

Turner, V. (1993). Antropologia della performance. Bologna: Il Mulino.

Varela, F. (1999). Ethical Know-How: Action, Wisdom, and Cognition. Stanford: Stanford University Press. 
Performative Didactics in a Technological Environment

Carlomagno N., Cordella F.M, Minghelli V., Rivoltella P.C.

Varela, F. (2006). Neurophenomenology: A Methodological Remedy for the "Hard Problem". Journal of Consciousness Studies», vol. III, n. 3, 330-349. In Cappuccio, M, (trad. it. a cura di). Neurofenomenologia. Le scienze della mente e la sfida dell'esperienza cosciente (pp. 65-93). Milano: Bruno Mondadori.

Vygotskij, L.S. (1972). Immaginazione e creatività nell'età infantile. Roma: Editori Riuniti. 